\author{
Pawel Żebrowski
}

\title{
Договор АСТА - защита интеллектуальной собственности или попытка ограничения свободы в интернете?
}

\section{1. Введение - что же такое АСТА?}

Международное соглашение по борьбе с контрафактной продукцией [англ. The AntiCounterfeiting Trade Agreement (ACTA)] - вынесенное на рассмотрение многостороннее торговое соглашение, согласно которому будет установлено строгое наблюдение за соблюдением авторского права в Интернетеи на рынке информации и информационных технологий и товаров, основанных на информационных технологиях. Это соглашение обсуждалось правительствами США, Японии, Швейцарии, Австралии, Новой Зеландии, Южной Кореи, Канады, Мексики и Европейской комиссией ${ }^{1}$.

АCТА в замысле авторов должна являться частью стратегии, применяемой торговыми представителями США, Евросоюза, Японии и других стран, поддерживающих ужесточение контроля за нарушениями авторского права. На протяжении 6 лет правительства многих стран вынашивали идею международного сотрудничества, направленного на борьбу с нарушениями прав интеллектуальной собственности в глобальном масштабе.

Идея о соглашении по борьбе с контрафакцией родилась на 31-м саммите Группы Восьми в шотландском городе Глениглс в 2005 году, когда представители Японии выдвинули идею о необходимости повышенного внимания к вопросам защиты правообладателей ІТ-продуктов и цифрового контента.

Подготовительный период создания международного договора длился в течение 6 лет и насчитывал 10 раундов переговоров. В 2006 году к Японии присоединились США, которые совместно с японцами обратились к партнерам из других стран с предложением развивать идею многостороннего сотрудничество по борьбе с контрафакт-

1 А. Гейгер, A View From Europe: The high price of counterfeiting, and getting real about enforcement [online]. The Hill [Доступ: 2013-06-06]. Доступны на: <www.thehill.com/ acta/04/06/2012/pdf $>$. 
350 | Adam Mickiewicz University Law Review

ной продукцией и пиратством. 23 октября 2007 года было официально объявлено о начале переговоров, к которым к тому времени подключились Европейский Союз и Швейцария.

Стоит подчеркнуть, что переговоры проводились за закрытыми дверями без участия представителей многих стран и даже международных организаций, таких как ЮНЕСКО, ВОИС и прочих, на позицию которых могли повлиять проштрафившиеся в вопросах пиратства страны. Текст документа также не разглашался, однако в мае 2008 года черновая версия соглашения всё же просочилась через Wikileaks.

Днем Рождения Торгового соглашения АСТА считается 1 октября 2011 года. Хотя соглашение подписали на тот момент только 8 государств, к нему в ближайшем будущем планировали присоединиться Европейский Союз, Швейцария и Мексика. Соглашение должно вступить в силу после того, как депозитарию соглашения (Японии) будут переданы документы о его ратификации как минимум в 6 подписавшихся странах. В преддверье церемонии подписания 30 сентября в японском городе Сендай прошел посвященный АСТА симпозиум, на котором были освещены основные положения документа и прозвучали призывы о присоединении к соглашению для торговых партнеров стран-участниц.

Итак, подводя первый итог, можно сказать, что АСТА - Торговое соглашение по борьбе с контрафактом:

- направлено на борьбу с воровством интеллектуальной собственности в сети Интернет, а также на рынках программных и цифровых продуктов, особенно в странах с высоким уровнем пиратства (в числе которых Польша и Россия);

- предусматривает укрепление международного сотрудничества в части продвижения эффективных методов защиты правообладателей, а также взаимное признание патентов между подписавшимися государствами;

- стимулирует создание законодательной базы для выявления и наказания нарушителей авторских и смежных прав;

- основывается на стандартах Соглашения ВТО по торговым аспектам прав интеллектуальной собственности (ТРИПС) с целью их дальнейшего ужесточения 2 .

\section{2. Опасения, связанные с АСТА}

Все же, несмотря на громкие замыслы авторов Соглашения, периода внедрения АCTA с опасениями ожидало все мировое сообщество, ведь некоторые положе-

2 Против кого направлен новый международный договор ACTA [online]. Copyright Aвторское Право [Доступ: 2013-06-02]. Доступны на: <http://www.copyright.ru/news/ main/2011/10/12/ACTA>. 
ния АСТА с трудом балансировали на грани жестких мер и даже нарушения прав и свобод человека. Так, к примеру, по условиям соглашения:

- работники таможни на границах подписавших договор АСТА государств получат право проверять содержимое портативных цифровых устройств (мобильных телефонов, плееров, ноутбуков и пр.) с целью поиска нелегального контента и программного обеспечения;

- провайдеры будут обязаны по первому требованию правообладателей удалять нелегальный контент, а также предоставлять всю личную информацию о нарушителях;

- будет разрешен обыск на частных территориях с целью поиска контрафакта, а также немедленное изъятие и ликвидация любого оборудования, применяемого для производства и использования нелегальной продукции.

Для вышеописанных действий не потребуется ни соответствующего судебного предписания, ни доказательств факта пиратства как такового ${ }^{3}$. Естественно, столь недемократичный подход вызвал волну критики со стороны общественных организаций, руководства стран с высоким уровнем пиратства и многих отраслевых экспертов.

Перспектива подписания соглашения АСТА столкнулась в Европе с волной критики. Резкие протесты против АСТА прокатились по многим странам Евросоюза. Противники нового закона усмотрели в нем репрессивную составляющую, которая поможет властям в цензуре Интернета, установлении сетевого контроля над свободными гражданами и ущемлении их базовых прав.

Поводом для недовольства формально послужила также готовность Евросоюза к ратификации международного Торгового соглашение по борьбе с контрафактной продукцией (Anti-Counterfeiting Trade Agreement, ACTA).

Организация Access, выступающая против принятия данного законопроекта, организовала всемирный день протеста 11 февраля 2012, чтобы показать Европейскому парламенту необходимость отказа от ратификации АСТА. Протесты прошли более чем в 200 европейских городах, на улицы вышли десятки тысяч протестующих. Самыми многочисленными были выступления в Германии, Польше и Голландии. В Германии на улицы вышли более 25 тыс. демонстрантов. В Софии - 10 тыс. человек, в Бухаресте - порядка трехсот, в Берлине - более 2 тыс., в Мюнхене - около 16 тыс. человек. Демонстрации также прошли в Лондоне, Варшаве, Праге, Вильнюсе, Братиславе, Париже, Брюсселе, Дублине и других городах ${ }^{4}$.

3 Полный текст Международного соглашения по борьбе с контрафактной продукцией [online]. Foreign Affairs, Trade and Development Canada [Доступ: 2013-06-04]. Доступны на: $<$ http://www.international.gc.ca/trade-agreements-accords-commerciaux $>$.

4 С. Попсулин, Европу сотрясли демонстрации против тайного закона о копирайте [online].Издание о высоких технологиях [Доступ: 2013-06-06]. Доступны на: <http:// www.cnews.ru/news/top/index.shtml?2012/02/13/477294>. 
352 | Adam Mickiewicz University Law Review

Протестующие утверждали, что АСТА значительно сократит возможность свободно выражать свое мнение в интернете. В то же время сторонники законопроекта настаивали, что соглашение не вносит каких-либо изменений в действующие законы и лишь защищает права авторов на фоне активного развития пиратства в интернете. Они подчеркивают, что во время обсуждений всегда выступали за открытость принципов соглашения.

\section{3. Реакция на АСТА общественности и политиков в Польше}

Движение, выступающее против принятия АСТА, также широко поддерживалось членами хакерской группировки Anonymous, которые взяли на себя ответственность за взлом многих сайтов министерств и ведомств. Именно группировка Anonymous причастна к тому, что 23 января 2012 года, ряд веб-сайтов польского правительства (в том числе сайты президента, сейма, министерства культуры, канцелярии премьер-министра) были недоступны в результате направленных на них DDOS-атак. Именно это придало в Польше медиальную огласку вопросам и проблемам, связанным с АСТА. Ряд польских сайтов и социальных сетей объявил о том, что они устраивают акции протеста против намерения Польши подписать АСТА.

Общество активно заинтересовалось проблемой АСТА и все в более убедительных формах демонстрировало свое несогласие на подписание Соглашения. Уже 24 января более тысячи человек протестовали перед Информационным Бюро Европейского Парламента в Варшаве; 25 января, по крайней мере, 15000 демонстрантов выражали протест в Кракове, 5000 во Вроцлаве, и в других городах страны. 27 января, протестующих по всей стране насчитывалось десятки тысяч ${ }^{5}$.

Полемика в польском Парламенте также была очень напряженной. 26 января 2012 года группа польских политиков выразила неодобрение договора, надев маски Гая Фокса во время парламентских разбирательств. Изображения этого события быстро распространились в интернете. Польская оппозиция правой партии Право и Справедливость впоследствии призывала к референдуму по АСТА.

3 февраля 2012 Премьер-министр Польши Дональд Туск заявил о приостановке процесса ратификации антипиратского закона, который вызвал массовые протесты интернет-пользователей страны. По словам премьера, закон все ещё может вступить в силу, однако это должно произойти только после общественной дискуссии, в которой должны принять участие как правообладатели, так и обычные пользователи интернета ${ }^{6}$.

5 Премьер Польши отказался ратифицировать антипиратский закон [online]. Lenta.ru [Доступ: 2013-06-15]. Доступны на: <http://lenta.ru/news/2012/02/04/acta/>.

6 Премьер Польши отказался ратифицировать антипиратский закон [online]. Lenta.ru [Доступ: 2013-06-15]. Доступны на: <http://lenta.ru/news/2012/02/04/acta/>. 


\section{4. Позиция Европейского Союза по АСТА}

Правительственные учреждения Европейского Союза принимали активное участие в полемике касательно Торгового соглашения по борьбе с контрафактной продукцией АСТА. Дискуссии, действительно, были очень жаркими и принимали при этом разный характер: от попыток развенчать основные мифы о новом международном договоре и оправдать подписание соглашения до однозначных сомнений в соответствии АСТА фундаментальным правам и гражданским свободам.

Что примечательно, Кадер Ариф, докладчик Европейского парламента по АCTA, подал в отставку со своего поста ещё в 26 января 2011 и осудил договор caмым решительным образом реализуя свое намерение послать четкий сигнал и предупредить общественное мнение об этой неприемлемой ситуации и отказываясь принимать участие в этом маскараде 7 .

Важно заметить, что некоторые комитеты Европарламента в процессе голосования не оказали поддержки антипиратскому договору АСТА, посвященному борьбе с контрафактной продукцией. Противники принятия этого договора - это Комитет, занимающийся гражданскими свободами, Комитет по вопросам промышленности, энергетики и исследований, Юридический комитет. Особо значимым было также решение Комитета Европарламента по международной торговле, который проголосовал против ранее получившего противоречивые оценки Торгового соглашения по борьбе с контрафакцией АСТА. По мнению многих экспертов, именно это стало смертельным ударом для всего проекта АСТА.

12 депутатов комитета проголосовали за принятие АСТА, 19 были против. С процессуальной точки зрения, это была последняя стадия рассмотрения проекта соглашения перед решающим голосованием в Европейском парламенте. Как правило, голосование комитета является формальной рекомендацией для голосования в ЕП. Депутаты Европарламента теперь могли либо принять АСТА в нынешнем виде, без оговорок, или проголосовать против.

Один из лидеров комитета, британский депутат ЕП Дэвид Мартин, заявил после голосования, что комитет проголосовал не против интеллектуальной собственности как таковой, а против АСТА - неудачного документа, который оставляет много вопросов без ответа ${ }^{8}$. Одно из главных опасений Комитета заключалось в том, что АСТА не соответствует основным правам человека. Кроме того, модель, которую АСТА пред-

7 J. Baker, IDG News. Opposition to ACTA Swells in Europe [online]. PCWorld [Доступ: 2013-06-12]. Доступны на: <http://www.pcworld.com/article/249456/ opposition_to_acta_ swells_in_europe.html>.

8 Антипиратский договор АСТА близок провалу [online]. Новости DELFI [Доступ: 2013-06-06]. Доступны на: <http://rus.delfi.ee/daily/euroopa/ antipiratskij-dogovor-acta-blizok-k-provalu.d?id $=64577060>$. 
354 | Adam Mickiewicz University Law Review

лагает для защиты интеллектуальных прав, опирается на устаревших представлениях о цифровой информации.

В итоге, в решающем голосовании 4 июня 2012 года Европарламент проголосовал против АСТА - 478 депутатов проголосовали против, 39 - за, 165 воздержалось. Европарламент решил, что в том виде, в котором соглашение сейчас существует, оно противоречит даже самым основным правам человека, которые декларирует Евросоюз. Также оно оказывает влияние на правовую базу Евросоюза, так как вступает с ней в противоречия 9 .

Таким образом, Соглашение АСТА постигла участь так называемой натуральной смерти, так ранее от него отказались Австралия, Швейцария и Мексика - соответственно ввести соглашение в жизнь можно было только в нескольких странах, что расходилось с замыслами авторов АСТА.

\section{5. Заключение}

Общепризнанно, что убытки правообладателей от повсеместно распространенного пиратства составляют очень серьезные суммы. Поэтому вполне объяснимы участившиеся в последние годы попытки поддержать интеллектуальные права, расширив и ужесточив средства их защиты. Такие попытки реализуются правообладателями и в сфере принятия международных, региональных или двусторонних соглашений, и лоббирования национальных законопроектов, и создания судебных прецедентов, а затем и единообразной судебной практики.

Очень часто при этом возникает угроза ущемления основополагающих прав на свободу слова, свободу распространения информации, неприкосновенность частной жизни, доступ к культурным ценностям. Нередки случаи злоупотребления интеллектуальными правами: часто основную прибыль от использования интеллектуальных результатов получают совсем не их авторы, а различные посредники. Часто развитие технологий встречает серьезные препятствия в виде узаконенных и максимально расширенных монополий отдельных участников, а их силы истощаются в бесконечных патентных войнах ${ }^{10}$.

И нельзя сказать, в итоге, что выигрывают от этого только правообладатели или только пользователи. Пожалуй, что проигравших тут гораздо больше. В этой ситуации стоит лишний раз вспомнить, что один из базовых принципов права интеллектуальной собственности - обеспечения баланса интересов правообладателей и общества. Именно в этом направлении и должны прилагаться основные усилия. Важнее всего попыт-

9 A. Souppouris, EU Parliament rejects ACTA [online]. The Verge [Доступ: 2013-06-06]. Доступны на: <http://www.theverge.com/2012/7/4/3136773/acta-no-vote-eu-parliament-meps>.

10 Общий обзор Анти-Контрафактного Торгового Соглашения [online]. Lex Digital Blog [Доступ: 2013-06-02]. Доступны на: <http://lexdigital.ru/2012/019/>. 
ки отыскать новые точки равновесия взаимных интересов, а не хорошо укрепленные рубежи обороны.

Заблуждаются те, кто призывает к полному отказу от интеллектуальных прав (труд любых людей должен достойно вознаграждаться, и авторы тут - не исключение), но не совсем правы и те, кто пытается всеми силами удержать сложившееся положение, подпирая ветхое жилье все новыми и новыми бетонными балками, от этого оно не станет более привлекательным и приносящим прибыль ${ }^{11}$.

Достижение баланса интересов сторон вполне возможно. Проекты разработать не так уж сложно. Главное, это, конечно, общее осознание и принятие необходимости перемен, рассмотрение таких предложений на международном уровне и более-менее единогласное им следование. А пока мы не пришли к этому поворотному моменту важно наблюдать за тенденциями изменений в сфере использования интеллектуального продукта, распространять положительный, направленный на поиск компромисса опыт, и открыто противостоять попыткам решить проблемы за чужой счет, извлечь сиюминутную выгоду, похоронив при этом веру в возможность нахождения согласия.

\section{Биографическая аннотация:}

Paweł Żebrowski - студент факультета права и администрации Университета им. Адама Мицкевича в Познани. Научные интересы: международное и европейское право; современные международные отношения.

\section{SUMMARY}

\section{Acta Agreement - protection of intellectual property rights or attempt to limit Internet freedom}

The aim of the study is to analyse the Acta Agreement in the context of the question whether it is a form of protection intellectual property rights or an attempt to limit Internet freedom. The author presents the Acta Agreement content, concerns about it, social reaction and European Union standing.

KEYwords: Acta Agreement, intellectual property rights, Internet freedom

11 Общий обзор Анти-Контрафактного Торгового Соглашения [online]. Lex Digital Blog [Доступ: 2013-06-02]. Доступны на: <http://lexdigital.ru/2012/019/>. 
